\title{
Effects of Jigsaw IV Cooperative Learning Strategy on Students' Academic Performance in Organic Chemistry in Zaria Education Zone, Kaduna State, Nigeria
}

\author{
Ibrahim Mohammed, ISA \\ Dr. Binta Asabe MUHAMMAD \\ Department of Chemistry, School of Science, Federal College of Education, Zaria
}

\begin{abstract}
This study investigated the effects of Jigsaw IV Cooperative Learning Strategy (J4CLS) on Students' Academic Performance in Organic Chemistry in Zaria Education Zone. A pretest and posttest Quasi-experimental research design was used for the study which featured two groups (Experimental and Control groups). The experimental group was exposed to Jigsaw IV Cooperative Learning Strategy while the control group was taught using Conventional Method of Teaching (CMT). A Sample sizes of 234 students selected from two Senior Secondary Schools in Zaria Education zone was used as the study sample, drawn from a population of 11 schools with a total of 1154 students. The two schools selected, were pretested, to find their academic equivalence before the treatment. The instrument developed was Organic Chemistry Performance Test (OCPT) with a reliability coefficient of 0.88 was used for data collection. The data collected was analyzed using Mean scores, Standard deviation, Analysis of Covariate (ANCOVA) and t-test statistics at $\mathrm{P} \leq 0.05$ level of significance. The findings indicated that, there is significant difference between the mean performance scores of science students taught Organic Chemistry concepts with Jigsaw IV Cooperative Learning Strategy and their counterparts taught with CMT in Zaria Education zone. However, students' gender had no influence on their academic performance. Based on the findings, it was recommended among others that Chemistry teachers should incorporate into main streams of pedagogy in the teaching of chemistry at Senior Secondary Schools the use of Jigsaw IV Cooperative Learning Strategy to improve students' cognitive and affective outcomes among others.
\end{abstract}

Keywords: Jigsaw IV Cooperative Learning Strategy, Academic Performance, Organic Chemistry

DOI: $10.7176 / \mathrm{CMR} / 11-9-03$

Publication date: November $30^{\text {th }} 2019$

\section{Introduction}

The relevance of science to national goals, aspirations and economy dictates to a large extent, the huge commitment and support which nations make and give to science and technology advancement. This may be the reason why Achor (2006) and Ada (2008) opined that as a result of the speed at which the world is changing technologically, the need and usefulness of teaching and learning of science therefore cannot be over looked. The classification of any nation into developed, developing and underdeveloped could be measured accurately by the number of chemists, physicists, engineers, pharmacists, doctors, agriculture and science educators the nation could produce (Agogo, 2009, Maduawesi, Aboho \& Okwuedei, 2010).

The importance of chemistry to our life cannot be over emphasize. This is because Chemistry is everywhere and Chemistry investigates the world around us and has contributed greatly towards providing us with basic needs of life such as food, clothing materials, housing materials, drugs, transportation, fertilizers, insecticides, and so on (Oloyede, 2010; Opara \& Waswa, 2013; Ababio, 2007). Despite the key role of Chemistry as the central science that forms the basic foundation to many disciplines and in improving the quality of life, the performance of Nigeria secondary school students in the subject has for many years remained a matter of a serious concern (Jegede, 2010; Oloyede, 2010).

Adegoke (2011) reported that students are not actively involved in developing knowledge; they receive information passively and are less motivated. The instructional method employed by the teacher plays an important role in the acquisition of skills and meaningful learning. However, the lecture method uses by teachers have been criticized because only hardworking students can benefit from it. This situation has spurred researchers in Science Education and Educational Psychology to investigate the ways in which science students would learn science through meaningful interaction in a rich classroom environment. Several teaching strategies have been advocated for use in science and mathematics classrooms, ranging from teacher-centered approach to more students-centered ones (Zakari \& Iksan, 2007). One of such methods according to Oloruko-oba, (2001) is Cooperative Learning Strategy.

Cooperative learning is an instructional strategy whereby students are encouraged to work together on learning tasks (Maden, 2011). In cooperative learning, students work face to face to complete a given task collectively. Cooperative learning setting encourages students to work together to attain group goals, instead of 
working individually or competitively (Zakaria \& Iksan, 2007). Students discuss subject matter, help each other learn, and provide encouragement for members of the group. Positive interdependence where each student must believe that they have a key role to play in the group; individual accountability where each student within a group must be accountable for mastery of the instructional content presented; group rewards that entails sufficient incentives for the group to work together; and group training that entails social skills for effective collaboration among others the key elements of cooperative learning (Johnson \& Johnson, 2009 \& Maden, 2011)). Therefore, to enhance the understanding of Organic Chemistry concepts, students must be more active in the classroom and must creatively acquire knowledge, especially in understanding and solving physics problems. According to Gumel,(2015) students should be given the opportunities to develop, interact, and share with friends through cooperative learning activity, so that the cognitive and affective development of students in science can be improved.

There are many cooperative models that are designed to achieve different objectives and one which is Jigsaw model. This study focused on Jigsaw IV cooperative learning strategy. There are six types of Jigsaw strategies currently in use but Jigsaw IV had received attention and widely used for effective classroom instruction (Zakaria, Solfitri, Daud \& Abidin, 2013). Jigsaw cooperative learning requires students to work in group of five to six members. Each student in a group is given information to which no one else in the group has access, thus making each student an "expert" on his or her section of the subject matter. Members of different teams who have studied the same sections meet in "expert groups" to discuss their sections and learn how to teach their colleagues in home group. Then the students return to their original teams and take turn to teach their teammates what they have learnt. All students in a group are expected to learn all the subject matter assigned to each member of their group. However, Jigsaw IV includes three important new features: an introduction, quizzes, and re-teaching after individual assessment (Holliday, 2000).

In order to stimulate student interest in the lesson, the teacher first introduces the lesson by means of lectures, presentation of literature, questioning, proposing problems, or perhaps showing a movie in a 'plenary' class session. Students are then assigned to a heterogeneous group "the home group" and all students are assigned topics to read. Here each student discusses the expert sheet that is based on a list of all topics. Again, the students with the same expert sheet move to their expert group to discuss their topic. In order to check accuracy and understanding of students in the expert group, they are assessed by means of a quiz - this being based on the expert sheet. They return to their home group, teach all their group members and take quizzes all based on the original material. The teacher reviews and clarifies any concepts which it appears the students did not understand. The students take individual quizzes, and scores are combined to produce an overall team score. Finally, the teacher re-teaches any material which was misunderstood after the individual assessment process.

Several studies show that Jigsaw Cooperative Learning Strategy is a learning strategy that enhances students understanding and academic performance in Physics (Hanze and Berger, (2009); Keramati, (2010); Gambari, Olumorin and Yusuf (2012)), in Chemistry (Doymus, (2008); Jansoon, Somsook and Coll, (2008); Gumel, (2015)), in Mathematics (Timayi, Bolaji, \& Kajuru,(2015)) reported that Jigsaw IV is considerably more effective than individualistic instructional strategy and conventional classroom instruction respectively. However, Shaaban (2006), Seaborn and Wilson (2002) found no significant difference in the achievement of students taught using Jigsaw cooperative learning strategy and those taught using conventional classroom and discussion methods respectively. The findings on the use of Jigsaw cooperative learning are inconclusive; therefore, this study examined the effects of Jigsaw IV on students' performance in Organic Chemistry.

Globally, there have been debates on students' performances in Science and Mathematics with respect to gender, which has continued to be of interest and inconclusive (Stoet, \& Geary, 2013). Gender has been identified as one of the factors influencing students' performance in sciences at senior secondary school level. Olson (2002) reported that, female students performed better than males students when taught Mathematics and sciences using cooperative learning. Sadker in Lakpini (2006) revealed that male students received more criticism from their teachers than their female counterparts as such that affects their performance in sciences (chemistry). Contrarily, Khairulanuar, Nazre, Sairabanu and Norasikin (2010) found gender differences in favour of male students. Becker in Lakpini (2006) opined teachers spoke more frequently to boys, asked the boys more questions, praised boys for quality work and girls for neatness. Even though, Ajaja and Eravwoke (2010) and Timayi et al (2015), reported that gender had no effect on academic achievement of students in cooperative learning. These contradictory findings have caused for inclusion of gender as one of the moderating variable for this study.

The reviewed show the inconclusiveness of the findings on cooperative learning on Academic performance and gender of the learners. Furthermore, previous studies focused on comparative effects of cooperative learning strategy and conventional classroom instruction without examining the effectiveness Jigsaw IV cooperative learning setting on Students' Performance in Organic Chemistry in Zaria Education Zone, Kaduna State. Based on these facts the present study examined the effects of Jigsaw VI cooperative learning strategy on secondary school students’ Academic Performance in Organic Chemistry in Zaria, Kaduna State. 


\section{Research Questions}

The study addressed the following research questions.

(i). Is there any difference in the performance of secondary school students taught Organic Chemistry using Jigsaw VI cooperative settings and those taught using Conventional Method Teaching (CMT)?

(ii). Is there any difference in the performance of male and female students taught Organic Chemistry using Jigsaw VI cooperative settings?

\section{Research Hypotheses}

The following null hypotheses were tested in the study.

(i). There is no significant difference in the performance of secondary school students taught Organic Chemistry using Jigsaw VI cooperative settings and those taught using Conventional Method Teaching (CMT).

(ii). There is no significant difference in the performance of male and female students taught Organic Chemistry using Jigsaw VI cooperative settings.

\section{Methodology}

The design of this study is a quasi-experiment consisting of treatment group and a control group, since the classes existed as intact groups. Pre-test was used to determine the equality of the two groups. The experimental group was taught Organic Chemistry using Jigsaw (IV) Cooperative Learning Strategy for the period of six weeks. The control group was also exposed to the same concept for the period of six weeks.

A simple random sampling technique was used to select two secondary schools in Zaria Education zone, Kaduna State, Nigeria. These schools were selected based on the following criteria: equivalence (laboratories, facilities and manpower), school ownership (public schools), gender composition (mixed schools). Intact classes were used in each of the two schools selected and randomly assigned to experimental (Jigsaw IV) and control (Conventional Method of Teaching, CMT) groups using simple random sampling technique.

The study consists of 234 students from two groups which comprised of 124 students in the control group and 110 students in the treatment group. Treatment group was exposed to jigsaw IV cooperative learning (J4CLS), while the control group was taught with Conventional Method of Teaching (CMT). The students in the experimental group were heterogeneously divided into groups with 3-5 members each, composed of students of different gender. To avoid bias in grouping, team portrait and team vision statement were used in the school.

The instrument used for the study was Organic Chemistry Performance Test (OCPT) developed by the researcher to measure the students' performance in Organic Chemistry before and after exposed to J4CLS. The OCPT comprises forty (40) items. The instrument was validated by team of experts at the Department of Science Education, Faculty of Education and Chemistry Department, Faulty of Physical Sciences, Ahmadu Bello University Zaria. The reliability of the OCPT was determined from one shot test administered and the scores was subjected to Cronbach Alpha coefficient, using Statiscal Package for Social Sciences (SPSS) and the value obtained was $r=0.88$. This value suggests that the test questions was reliable and as such would test what it is designed to test. The data collected during the study was analysed using Analysis of Covariance (ANCOVA) and t-test statistics using Statistical Package for Social Sciences (SPSS) version 21 at 0.05 alpha level.

\section{Results}

The results are presented based on the research hypotheses:

HO1: There is no significant difference between the mean performance scores of students taught Organic Chemistry using the Jigsaw IV Cooperative Learning Strategy and those taught using the Conventional Method of Teaching among SS II Students in Zaria Educational Zone.

Table 1: ANCOVA Post-test Comparison of Mean Performance Scores of Experimental (Jigsaw IV) and Control (CMT) Croups

\begin{tabular}{lllllll}
\hline Source of Variation & $\begin{array}{l}\text { Type III Sum of } d f \\
\text { Squares }\end{array}$ & Mean Square & F & Sig. & Remark \\
\hline Covariate (pretest) & 4.957 & 1 & 4.957 & 0.179 & 0.673 & $*$ NS \\
Intercept & 58651.720 & 1 & 58651.720 & 2114.750 & 0.001 & $*$ S \\
Group (Treatment) & 3648.616 & 1 & 3648.616 & 131.555 & 0.001 & $*$ S \\
Corrected Model & 3649.088 & 2 & 1824.544 & 65.786 & 0.001 & $*$ S \\
Residual (Error) & 6406.690 & 231 & 27.735 & & & \\
Total & 151152.000 & 234 & & & & \\
\hline
\end{tabular}

Where $* \mathrm{~S}=$ Significant at $\mathrm{P} \leq 0.05, * \mathrm{NS}=$ Not significant

Table 1 shows the main effect of experimental group (J4CLS) on students performance which produced an $\mathrm{F}=131.555$, $\mathrm{P}$ value of 0.001 ) was significant, this indicates that the method of instruction produced a significant 
effect on the posttest performance scores of students in the experimental group. Therefore, the null hypothesis one which states that 'there is no significant difference in the mean performance scores of students taught Organic Chemistry concepts using the J4CLS and those taught using the Conventional Method of Teaching' is hereby rejected.

HO2: There is no significant difference between the mean performance scores of male and female Students taught Organic Chemistry using Jigsaw IV Cooperative Learning Strategy in Organic Chemistry.

Table 2: t-test Analysis of Mean Performance Scores of Male and Female Students in the Experimental Group

\begin{tabular}{llllllll}
\hline Sex & $\mathrm{N}$ & Mean & Std. Deviation & $t$-cal. & Df & P value & Remark \\
\hline Male & 73 & 30.47 & 5.677 & & & & $*$ *NS \\
$\begin{array}{l}\text { Female } \\
\text { Total }\end{array}$ & 37 & 28.86 & 4.979 & 1.46 & 108 & 0.857 & \\
\hline
\end{tabular}

Significant at $\mathrm{P} \leq 0.05, * \mathrm{NS}=$ Not significant

Table 2, shows that there is no significant difference in the posttest scores of male and female Chemistry students taught Organic Chemistry concepts using Jigsaw IV Cooperative Learning Strategy. This is simply because the $t$-cal. which is 1.46 and $p$-Value of 0.857 which is greater alpha value of 0.05 level of significance. Therefore, the null hypothesis which states that 'there is no significant difference in the mean achievement scores of male and female students taught Organic Chemistry concepts using Jigsaw IV Cooperative Learning Strategy' is hereby retained.

\section{Discussion of Results}

The results of the analyses related to the hypothesis one indicated a significant difference in students' performance of in favour of those in the experimental group (Jigsaw IV). Findings indicated significant difference exists between the mean performance scores of students exposed to Jigsaw IV Cooperative Learning Strategy and those taught using Conventional Method of Teaching. The findings as regards to better performance of students in the J4CLS setting as compared to the CMT agree with earlier findings of Yusuf, Gambari and Olumorin (2015) in physics; Timaye etal (2015) in mathematics and Mari and Gumel (2015) in Chemistry which reported that students taught using J4CLS and other Jigsaw cooperative method performed better than those taught using conventional method of teaching. However, the finding disagree with the findings of Shaaban (2006), Ross, Seaborn and Wilson (2002) and Thompson and Pledger (1998) who found no significant difference in the achievement of students taught using Jigsaw and those taught using conventional classroom and discussion methods respectively.

This superiority of Jigsaw IV Cooperative Learning Strategy stems from the fact that it was a task structured, that is the students were divided into small groups of 5-6 known as the Jigsaw groups, and the concept to learn was broken into segments. Each student in the Jigsaw group was assigned a segment to specialize on as all students with same topic or segment to form the expert groups. After the discussion and elaboration at the expert group, the students reconvened at their Jig-saw groups where each expert explained his/her topic to other member of the Jig-saw group after which they took up quiz individually without help or assistance from the other group members. This discussion and elaboration at both expert and jigsaw groups enhanced meaningful learning of the whole lesson as such produced a positive learning outcome. This was why significant difference exists and a better performance was observed on students taught using Jigsaw IV Cooperative Learning Strategy than those taught using chalk and talk method (Moreno, 2009).

The results of the analyses related to the hypothesis two indicated no significant difference in the performance of male and female students taught Organic Chemistry using Jigsaw IV cooperative learning strategy. This finding is in line with that of Adeyemi (2008); Ajaja and Eravwoke (2010); Yusuf, etal (2015); Timayi et al (2015) who individually found out that there is no gender difference in the academic performance of male and secondary school students exposed to Jigsaw IV Cooperative Learning Strategy. The finding is however in disagreement with that of Olson (2002) which reported that females performed better than males students when taught mathematics using Jigsaw II cooperative learning. This perhaps was due to the fact that the study was carried out at Western Australia University; perhaps students were not grouped into heterogenous groups of male female so as to enhance interactive effect of male and female students in the jigsaw groups. That might be the reason why the female students performed significantly better than their counterpart.

\section{Recommendations}

Based on the major findings of this study, the following recommendations are proffered.

(i) Teachers should expose Chemistry students to Jigsaw IV cooperative Learning strategy so as to improve students' performance in Chemistry. In addition, government, educational agencies and other education stakeholders should organize workshops on the use of J4CLS to enhance better performance 
of secondary school students.

(ii) Teacher education programme in Nigerian tertiary institutions should be improved upon to prepare teachers who can apply innovative teaching approach (J4CLS), which will promote effective teaching and learning.

(iiii) The use of Jigsaw IV Cooperative Learning Strategy seems to be appropriate in improving the performance of students in senior secondary schools Organic Chemistry. It should therefore, be incorporated into the main stream of pedagogy in the teaching of Chemistry and other science subjects at senior secondary schools in Zaria Educational Zone, Kaduna, Nigeria.

\section{REFERENCE}

Ababio, O.Y. (2007). New School Chemistry; Senior Secondary Science series, Lagos Africana Feb Publishers Ltd. 3-6

Achino, C. (2000). The Importance of Class Motivation to Learning Achievement. Journal of Curriculum Studies 7(1), 62-66.

Achor, E.E.(2006). Issues in Science and Society. Nsukka, Nigeria: Great A.P. Express Pub. Ltd.

Ada, N. A. (2008). The Challenge of Curbing Examination Malpractice in Nigeria's Educational System. Paper Presentation at the $5^{\text {th }}$ Faculty of Education National Conference, Benue State University. 3(2) 66-69

Adegoke, B. A. (2011). Effect of multimedia instruction on senior secondary school students' achievement in Physics. European Journal of Educational Studies 3(3), 537-541

Adeyemi, B. A. (2008). Effects of cooperative learning and problem-solving strategies on Junior Secondary school students' achievement in social studies. Electronic Journal of Research in Educational Psychology, 6(3), 691-708. http://www.springerlink.com/content/c19u25816754q5j5/12 ${ }^{\text {th }}$ January,2017

Agogo, P. O.(2009). Topics in Primary Science Education in Nigeria. Makurdi: Azaben Press

Agogo, P.O., Otor, E.E.(2013). Basic Issues of Chemistry Matter Ibadan, Nigeria: Optimism Press. 1-7

Ajaja, O. P. \& Eravwoke, O. U. (2010). Effects of cooperative learning strategy on junior secondary school students achievement in integrated science. Electronic Journal of Science Education, 14(1), Retrieved from http://ejse.southwestern.edu $13^{\text {th }}$ March, 2017

Doymus, K. (2008). Teaching chemical equilibrium with the Jigsaw Technique. Research in Science Education, (38) 249-260.

Gambari , I.A; Olumorin, C.O \& Yusuf, M.O, (2015) Effectiveness of Computer- Supported Jigsaw ii Cooperative Learning Strategy on the Performance of Senior Secondary School Students in Physics.

Gumel, S. A (2015). Effects of Jigsaw Model of Cooperative Learning on Self-efficacy and Achievement in Chemistry among Concrete and Formal Reasoners in Colleges of Education in Nigeria. Department of Science Education, Ahmadu Bello University, Zaria, 34-40.

Hanze, M. \& Berger, R. (2009). Cooperative learning, motivation effects, students Characteristics: An experimental study comparing cooperative learning and direct instruction in 12th grade physics classes. Learning and Instruction, 17(1), 29-41.

Holliday, D. C. (2000). The development of Jigsaw IV in a secondary social studies classroom. Lanham, MD: University Press of America, 23-25.

Jansoon, N., Somsook, E. \& Coll, R. K. (2008). The undergraduate chemistry practical learning experiences using the Jigsaw II method. Journal of Science and Mathematics Education in Southeast Asia, 31(2), 178200 .

Jegede, S. A. (2010). Nigerian Students Perception of Technical Words in Senior Secondary Schools Chemistry Curriculum. Department of Curriculum Studies, Faculty of Education, University of Ekiti, Ado- Ekiti, Nigeria. Pakistan Journal of Social Sciences 7(2), 109-111, ISSN:1683-8831

Keramati, M. (2010). Effect of cooperative learning on academic achievement of physics Course. Journal of Computers in Mathematics and Science Teaching, 29(2), 155 - 173. Chesapeake, VA: AACE. Retrieved on the $15^{\text {th }}$ April, 2017 from http://www.editlib.org/p/33121

Khairulanuar, S., Nazre, A.R., Sairabanu, O.K. \& Norasikin, F. (2010). Effects of Training Method and Gender on learning 2D/3D Geometry. Journal of Computers in Mathematics and Science Teaching, 29(2), 175 188. Chesapeake, VA: AACE. Retrieved on the $15^{\text {th }}$ April, 2017, from http://www.editlib.org/p/33188

Lakpini, M. A. (2006) Effect of a Conceptual Change Instructional Strategy On The $\backslash$ Achievement, Retention and Attitude of Secondary School Biology Students with Varied Ability. Unpublished PhD Dissertation, Ahmadu Bello University, Zaria.

Maden, S. (2011). Effect of Jigsaw I Technique on Achievement in Written Expression Skill. Journal of Educational Sciences: theory \& Practice, 11(2), 911-917.

Maduewesi B.U, Aboho DA, Okwuedei CA (2010). A practical guide to curriculum development. Onitsha, Nigeria: West and Solomon Publishing Co. Ltd.

Moreno, R. (2009). Constructing knowledge with an agent-based instructional Program: A comparison of 
cooperative and individual meaning making. Learning and Instruction, 19(5), 433 - 444.

Oloyede, O. I. (2010). Enhanced Mastery Learning Strategy on the Achievement and Self Concept in Senior Secondary School Chemistry. Humanity and Social Sciences Journal 5(1), 19-24.

Olorukooba, S.B. (2001). The Relative effects of instructional Cooperative Strategy and Traditional Method on Performance of Senior Secondary School Chemistry Students. An Unpublished Ph.D Dissertation, Department of Science Education, Faculty of Education, Ahmadu Bello University Zaria.

Olson, V. E. (2002). Gender differences and the effects of cooperative learning in college level mathematics. Unpublished Ph.D thesis, Curtin University of Technology, Perth, Western Australia.

Opara, F. \& Waswa, P.(2013) Enhancing students' achievement in Chemistry through the Piagetian Model: The learning Cycle. International Journal for Cross- Disciplinary Subjects in Education (IJCDSE), 4(4),12701278

Ross, M. C., Seabborn, A. W. \& Wilson, E. K. (2002). Is cooperative learning a

Valuable Instructional Method for Teaching Social Studies to Urban African American students? Retrieved February 5 2008, from http://www.eric.ed.gov/ERICWebPortal/Home.portal=(ED480458).

Stoet, G., \& Geary, D.C. (2013). Sex Differences in Mathematics and Reading Achievement are Inversely Related: within-and across-nation assessment of 10 years of PISA data. PLOS ONE, 8(3), 1-10.

Timayi, J. M., Bolaji, C. \& Kajuru, Y.K (2015). Effects of Jig-saw IV Cooperative Learning Strategy on Academic Performance of Secondary School Mathematics Students in Geometry. Department of Science Education, Ahmadu Bello University Zaria, Kaduna State, Nigeria. International Journal of Mathematics Trends and Technology. 28(1), 12-18

Thompson, M. \& Pledger, L. (1998). Cooperative learning versus traditional lecture format: A preliminary study. Retrieved from http://www.eric.ed.gov/ERICWebPortal/Home.portal, on 13/05/2017

Zakaria, E., Iksan, Z. (2007). Promoting Cooperative Learning in Science and Mathematics Education. A Malaysian Perspective," Eurasia Journal of Mathematics, Science \& Technical Education. 3(1), 35-39

Zakaria, E., Solfitri, T., Daud, Y. \& Abidin, Z. Z. (2013). Effect of Cooperative Learning on Secondary School Students' Mathematics Achievement. Creative Education, l.4(2), 98-100. Retrieved from (http://www.scirp.org/journal/ce). 